ville Foucalt nok sige, det har ingen betydning. Men det havde det lige akkurat, fordi det var mere prestigiøst at tilhøre gruppen af filosoffer end gruppen af simple historikere eller humanvidenskabsmænd. Og man har lige præcis brug for at "brække filosofien op med sociologiens koben", som Anders Fogh Jensen skriver s. 18 , fordi filosofien ikke selv har udformet redskaber til at forstå sin egen institutionelle historicitet. At renoncere på sociologiens koben er også at gå glip af et glimrende redskab til en kritisk sortering af Foucaults gode og dårlige ideer. Det gør det lettere at få øje på brudfladerne i Foucaults værk og dermed eksempelvis hans senere skepsis over for epistemernes historie og uviljen mod at forklare epistemiske skift i Ordene og tingene. Med inskriptionen af det foucaultske værk i dets tilblivelseskontekst bliver det også lettere at skelne de sider, der er båret af reel indsigt, fra de sider, der er præget af henvendelsen til et intellektuelt modepublikum - eksempelvis problemet med agens, som stammer fra den stærke modstilling af Sartres subjektfilosofi og strukturalismens filosofi uden subjekt, eller flotheder som 'menneskets død'.

Denne principielle og fra min side lidt syrlige (rønnebærrene, som man ved) diskussion af forholdet mellem filosofi og humanvidenskab skal imidlertid ikke skygge for alt det gode ved Anders Fogh Jensens bog. Med eller uden sociologiske koben kan man kun sympatisere med forsøget på at "vise, at Foucault nok er en original tænker, men at hans tanker ikke er faldet ned fra himlen" (s. 16), for det gøres med stort overblik og virkelig indsigt. Det samme gælder hele bogens bestræbelse på at gøre ledelseshistorikeren eller -tænkeren (peu importe!) Foucault så tilgængelig og begribelig som muligt - samtidig med at ledelsesproblemet sættes i sammenhæng med arven fra videnskabshistorien, så man undgår de amerikanske reduktioner til power/knowledge. Til det og meget andet er Anders Fogh Jensen en rigtig god guide. Nye Foucault-læsere kan med fordel begynde her, og selv de mest garvede vil nok kunne finde et og andet af interesse i denne originale fremstilling.

Carsten Sestoft

\section{Begreber og politik}

Kari Palonen: Die Entzauberung der Begriffe. Das Umschreiben der politischen Begriffe bei Quentin Skinner und Reinhart Koselleck, Lit Verlag Münster, 2004, 368 sider, $€ 34,90$

Siden 1980erne har der været fremført en række forsøg på at sammenligne Quentin Skinner og Reinhart Koselleck, som begge er kendt for deres historiske studier af sprog og begreber. Med den foreliggende bog overbyder den finske politolog Kari Palonen alle tidligere forsøg. Palonen er kendt som en af de ledende figurer $\mathrm{i}$ det internationale forskningsnetværk i begrebshistorie - History 
of Political and Social Concepts Group - og hans fortrolighed med Skinner og Kosellecks forfatterskaber er intet mindre end imponerende.

Die Entrauberung der Begriffe starter med en historiografisk introduktion til studiet af begreber. Her præsenteres først klassikere som Max Weber, George Sabine og Friedrich Meinecke, hvorefter Skinner og Koselleck placeres $\mathrm{i}$ deres formative 'intellektuelle kontekst' i henholdsvis England og Tyskland i 1950'erne og 60'erne. Herefter følger hele 247 siders introduktion til Skinners og Kosellecks forfatterskaber - med et fokus på deres intellektuelle profiler, tilgang til begreber, valg af tema og spørgsmål mm. Endelig afsluttes bogen med en opsummerende sammenligning af Skinner og Kosellecks tilgange til studiet af begreber (fokus er på politiske begreber) samt et forsøg på at videreudvikle disse tilgange.

Ifølge Palonen har Skinner og Koselleck det til fælles, at de er imod en ahistorisk og upolitisk tilgang til studiet af begreber: de understreger, at alle begreber har en historie, at de er foranderlige, og at der til alle tider foregår en kamp om at definere deres betydning. Deres specifikke tilgange til studiet af begreber adskiller sig imidlertid også. Hos Skinner studeres begrebers forandringer gennem analyser af, hvordan historiske agenter - oftest ledende politiske filosoffer - med skiftende intentioner foretager såkaldte 'retoriske omskrivninger' af bestemte begreber. Hos Koselleck studeres begrebers forandring mere strukturelt - ofte med det formål at aflæse hele samfunds overbevisninger, erfaringer og forventninger $i$ et tidsligt perspektiv. Palonen opsummerer forskellen således, at Quentin Skinners perspektiv på begrebsforandring er retorisk og Kosellecks tidsteoretisk.

I de sidste 30 års diskussion om lighederne og forskellene mellem Skinner og Koselleck har der til tider været en tendens til at fremhæve forskellene mellem de to. Skinner har bidraget til at forstærke denne tendens ved at hævde, at studier udelukkende af begreber er en umulighed, idet begreber altid indgår som en del af et større argument, og at det analytiske fokus derfor nødvendigvis må udvides. En af forcerne ved Palonens bog er imidlertid, at den understreger en række ofte uudtalte ligheder mellem de to forfatterskaber. Interessant er bl.a. demonstrationen af lighedspunkterne i Skinner og Kosellecks kritik af den stigende afpolitisering af politik; af deres fælles forkærlighed for det tabte, det glemte og det udgrænsede i historie; og af den fælles anskuelse af historiografi som en kontinuerlig Umschreiben der Geschichte. Ved at anskueliggøre disse ligheder viser Palonen, at de i temperament og stil utvivlsomt forskellige personligheder er åndeligt tættere beslægtede end ofte antaget.

Kapitlerne om Skinner og Koselleck er så voluminøse og detaljerede, at Palonens bog kan læses som to 
monografiske studier af de to historikere. Idet der endnu ingen monografiske studier foreligger af Koselleck og kun én om Skinner (også skrevet af Palonen) er Die Entzauberung der Begriffe en stor gevinst i den henseende. Palonens metodisk tætte læsning er i mange henseender grundig og omhyggelig. Med sin ihærdige sporing af, hvordan teorier, metoder og argumenter er opstået og har forandret sig over tid i de respektive forfatterskaber, forsøger Palonen bevidst at studere Skinner og Koselleck med deres egne metoder.

Man kunne dog diskutere, hvorvidt Palonens undersøgelse er baseret på samme antagelse af historisk foranderlighed, uforudselighed og tilfældighed, som kendetegner de to forfatterskaber. Det gælder bl.a. analysens bærende tese: at Skinner og Kosellecks begrebshistorie kan skrives tilbage til Max Weber. Tesen forekommer legitim, hvis man læser den som et element $\mathrm{i}$ en teoretisk konstruktion, hvor Weber (som Palonen har gjort andetsteds) gøres til opdageren af det begreb om 'politik som aktivitet', som Skinner og Koselleck har udviklet analysestrategier til studiet af. Men læser man tesen ind i Palonens sideløbende forsøg på at levere en idéhistorisk og kontekstuel forståelse af forfatterskaberne, er den derimod problematisk. Selv om Skinner i visse skrifter har behandlet Weber, er det svært at binde hans forfatterskab op på et Webersk udgangseller holdepunkt, og det er almindelig kendt, at Koselleck aldrig har påkaldt sig Weber som inspirationskilde i sin historieskrivning. Sat på spidsen kunne man således sige, at Palonen med sin fiksering af begrebshistorien hos Weber er tæt på at udøve den statiske og ahistoriske tilgang til studiet af sprog, begreber og idéer, som netop er blevet kritiseret af Skinner og Koselleck.

Palonen kunne måske have udfoldet de begrebshistoriske aspekter hos de to historikere på mere kompleks vis, hvis han havde nedtonet sit fokus på Weber til fordel for en mere omfattende afdxkning af de to forfatteres 'intellektuelle kontekst'. I tilfældet Koselleck hører vi næsten eller slet ikke om centrale inspirationskilder som Karl Löwith, Hans-Georg Gadamer og Martin Heidegger, hvilket spiller ind på Palonens problemer med at forklare og placere vigtige tematikker i forfatterskabet. Det gælder bl.a. den historiske antropologi (Kosellecks refleksioner over de antropologiske konstanter, der strukturerer og muliggør al historie), som Palonen andetsteds har kaldt et nyt og irriterende moment ved Kosellecks forfatterskab, selv om denne allerede i artikler fra 1960erne og 1970erne blev præsenteret som et helt centralt fundament for Kosellecks historiske tænkning.

Disse indvendinger skal imidlertid ikke afholde denne anmelder fra at anbefale Palonens bog. Rig på materiale, perspektiver og analyser - og kendetegnet af et usædvanligt engage- 
ment - er Die Entzauberung der Begriffe et must både for de, der interesserer sig for studiet af begreber og sprog, $o g$ for de, der interesserer sig for Skinner og Kosellecks forfatterskab.

Niklas Olsen

\section{Biosemiotik}

Jesper Hoffmeyer: Biosemiotik. En afhandling om livets tegn og tegnenes liv. Forlaget Ries, 2005, 464 sider, kr. 378,-

På forsiden af Jesper Hoffmeyers disputats, Biosemiotik. En afhandling om livets tegn og tegnenes liv, er der et lille billede af en fugl. Denne fugl har et ganske særligt forhold til honning, som den holder meget af. Men den har et problem, den kan ikke selv åbne de vilde biers reder. Boranfolket holder også af honning, og de residerer i samme område som fuglen (at dømme efter klippemalerier har boranerne indsamlet honning $\mathrm{i}$ 20.000 år). Deres problem er, at de har vanskeligt ved at finde biernes reder. I tidens løb har der udviklet sig et samarbejde mellem fuglen og menneskene, som går ud på, at fuglen leder boranerne frem til birederne ved hjælp af særlige kaldelyde, herefter ryger boranerne bierne ud og snupper honningen, fuglen tager derefter bivoksen og larverne, som er tilbage.

Indicator indicator kaldes fuglen (eller sorthalset honninggøg) og navnet er et glimrende eksempel på biologernes spontane semiotiske intuition.
En intuition, de ifølge Hoffmeyer, ellers ikke vil være ved!

Hoffmeyers afhandling er fyldt med eksempler på denne type af tegnudveksling mellem forskellige organismer; udveksling og samarbejde, der, vel at mærke, er til gavn for begge organismer. Men hvordan er sådanne samarbejder kommet i stand? Det er afhandlingens centrale spørgsmål. Der er næppe tale om, at honninggøgen har et gen for at føre boranerne fra træ til træ til bireder, alligevel er den god til det og leder boranerne frem til bierne på ca. en tredjedel af den tid, det ville tage dem selv.

Organismer, selv de mest simple, kan noget, som tilsyneladende er kendetegnende ved det at være levende. De udsender signaler, der kan aflæses som tegn, og temmelig ofte bliver signalerne opfattet som tegn. Tegnudvekslingen udvikler sig med tiden til en vane, hvis den altså er befordrende for organismernes overlevelse, hvorved der på naturlig vis opstår semiotiske relationer mellem organismerne. Fordelen ved semiotisk kommunikation frem for enstrenget biokemisk kausalitet, er den, at det giver et vist råderum - frihed: en celle eller en organisme kan reagere på forskellige måder alt efter på hvilket stadium i en proces, den befinder sig.

Vaner betyder i denne sammenhæng lovmæssighed. Begrebet stammer fra den amerikanske semiotiker, Charles Sanders Peirce (1839 - 1914), der beskrev naturlovene som vaner. Hoffmeyer citerer Peirce for føl- 